\title{
Asymptomatic ventricular dilatation precedes clinical decline in rodent adult chronic communicating hydrocephalus
}

\author{
Ignacio Jusue-Torres ${ }^{1 *}$, Jennifer Lu', Eric W Sankey ${ }^{1}$, Tito Vivas-Buitrago1', Joshua Crawford², Mikhail Pletnikov², \\ Jiadi Xư ${ }^{3}$, Ari Blitz ${ }^{4}$, Barbara Crain ${ }^{5}$, Alicia Hulbert ${ }^{6}$, Hugo Guerrero-Cazares ${ }^{1}$, Oscar Gonzalez-Perez ${ }^{7}$, \\ Alfredo Quiñones-Hinojosa', Pat McAllister ${ }^{8}$, Daniele Rigamonti ${ }^{1}$
}

From Hydrocephalus 2015

Banff, Canada. 18-21 September 2015

\section{Introduction}

The pathogenesis and behavioral effects of normal pressure hydrocephalus (NPH) are not fully understood, and the temporal relationship between radiological changes and neurological deterioration is unknown.

\section{Methods}

Bilateral subarachnoid injections of kaolin were administered in the cranial convexities of 20 adult rats. MRI was obtained using a Bruker Biospec 11.7 T MRI scanner at 14, 60, 90 and 120 days post kaolin injection. Locomotor, gait, and cognitive studies were performed independently every 2 weeks by faculty blinded to the imaging results. Tests included open field test, gait analysis, rotarod and novel object recognition. Logistic regression analysis was performed to assess association between ventricular size and clinical deterioration and rate of ventricular size enlargement and clinical deterioration.

\section{Results}

Radiological ventricular size showed progressive growth over time at all times $(\mathrm{p}<0.0001)$. The fastest ventricular enlargement happened within the first two months. No changes in gait, cognition, anxiety and general locomotor activity were detected during the first two months. The first gait deterioration occurred at 69 days; anxiety at 80 days; cognitive at 81 days and locomotor after 120 days. At the end of the study $66 \%$ of rats developed gait deterioration, $66 \%$ cognitive deterioration and $83 \%$

\footnotetext{
* Correspondence: ijusuet1@jhmi.edu

1Johns Hopkins University. School of Medicine, Department of Neurosurgery, USA

Full list of author information is available at the end of the article
}

anxiety changes. Ventricular enlargement was not associated with gait $(\mathrm{p}>0.05)$, cognitive $(\mathrm{p}>0.05)$ or anxiety $(p>0.05)$ deterioration. Locomotor deterioration was associated with ventricular size $(\mathrm{p}=0.014)$, speed of ventricular enlargement $(\mathrm{p}=0.015)$ and extension of injected kaolin ( $\mathrm{p}=0.04)$.

\section{Conclusions}

Kaolin injected in the subarachnoid space of adult rats can produce slow onset communicating hydrocephalus. Initially the ventricular enlargement seen on images is asymptomatic. Ventricular enlargement does not correlate with clinical impairment with exception of delayed locomotor impairment.

\begin{abstract}
Authors' details
${ }^{1} J o h n s$ Hopkins University. School of Medicine, Department of Neurosurgery, USA. ${ }^{2}$ Johns Hopkins University, School of Medicine, Department of Psychiatry and Behavioral Sciences, USA. ${ }^{3}$ Johns Hopkins University, School of Medicine, F. M. Kirby Research Center for Functional Brain Imaging at the Kennedy Krieger Institute, USA. ${ }^{4}$ Johns Hopkins University, School of Medicine, Department of Radiology and Radiological Science, USA. ${ }^{5}$ Johns Hopkins University, School of Medicine, Department of Pathology, Division of Neuropathology, USA. ${ }^{6} J o h n s$ Hopkins University, School of Medicine, Department of Oncology, USA. ${ }^{7}$ University of Colima, Facultad de Psicologia, Laboratory of Neuroscience, Mexico. ${ }^{8}$ Washington University, School of Medicine in St Louis, Department of Neurosurgery, USA.
\end{abstract}

Published: 18 September 2015

\section{References}

1. Sankey EW, Jusue-Torres I, Elder BD, et al: Functional gait outcomes for idiopathic normal pressure hydrocephalus after primary endoscopic third ventriculostomy. J Clin Neurosci 2015, 1-6.

2. Moran D, Kosztowski TA, Jusue-Torres I, et al: Does CT wand guidance improve shunt placement in patients with hydrocephalus? Clin Neurol Neurosurg 2015, 132:26-30. 
3. Jusue Torres I, Hoffberger JB, Rigamonti D: Complications Specific to Lumboperitoneal Shunt. Complications of CSF Shunting in Hydrocephalus: Springer. 2015, 203-11.

4. Elder BD, Sankey EW, Goodwin CR, Jusue-Torres I, Khattab MH, Rigamonti D: Outcomes and Experience with Lumbopleural Shunts in the Management of Idiopathic Intracranial Hypertension. World Neurosurg 2015, 1-6.

5. Jusué-Torres I, Hoffberger JB, Rigamonti D: Complications of Lumboperitoneal Shunts for Idiopathic Intracranial Hypertension. Cureus 2014.

6. Jusue Torres I, Hoffberger JB, Rigamonti D: Complications of Lumboperitoneal Shunts for Normal Pressure Hydrocephalus. Cureus 2014.

7. Elder BD, Bankah P, Blitz AM, et al: Core imaging in adult hydrocephalus. In Adult Hydrocephalus. Cambridge University Press;Rigamonti D 2014:110-20.

doi:10.1186/2045-8118-12-S1-013

Cite this article as: Jusue-Torres et al:: Asymptomatic ventricular dilatation precedes clinical decline in rodent adult chronic communicating hydrocephalus. Fluids and Barriers of the CNS 2015 12(Suppl 1):013.

\section{Submit your next manuscript to BioMed Central} and take full advantage of:

- Convenient online submission

- Thorough peer review

- No space constraints or color figure charges

- Immediate publication on acceptance

- Inclusion in PubMed, CAS, Scopus and Google Scholar

- Research which is freely available for redistribution

Submit your manuscript at www.biomedcentral.com/submit 